\title{
Human Resource Planning in Hospitality Industry
}

\author{
Sanjeev Kumar Saxena \\ Additional General Manager (Learning \& Development), \\ Jaypee Palace Hotel \& Convention Centre Agra, India.
}

CITATION: Saxena, Sanjeev Kumar (2019), "Human Resource Planning in Hospitality Industry", MERC Global's International Journal of Management, Vol. 7, Issue 3, pp. 247-253.

ARTICLE HISTORY: Submitted: March 15, 2019, Revision received: April 30, 2019, Accepted: May 12, 2019

ARTICLE TYPE: Research paper

\begin{abstract}
As human resource planning is the process by which a management determines how an organisation should move from its current manpower position to its desired manpower position. The main objective of Human Resource Planning is to have an accurate estimate of the employees required, fill the gap caused due to labour turnover, identify the areas of surplus or shortage of employees and to assess future accommodation requirement. It is an undisputed feature that the acquisition and utilisation of human resource have long-range impacts on the cycle of the organisation. It requires well-planned actions. The ineffective human resource planning deprives an organisation of several gains for its growth, which is offered by the environment. It signifies the enhanced importance of appropriate human resource planning. The aim of this paper is to explain human resource planning in the hospitality industry.
\end{abstract}

KEYWORDS: Human Resource, Planning, Labour turnover, Absenteeism, Retirement, Hospitality industry.

\section{BIBLIOGRAPHY}

1. Coleman, Bruce P. (1970), “An Integrated System for Manpower. Planning”, Business Horizons, Vol. 13, pp. 25.

2. Gupta, C. B. (1998), Human Resource Management, Sultan Chand and Sons, New Delhi.

3. Mamoria C. B, (1993), Personnel Management, Himalaya Publishing House, Bombay.

4. Nair, Sandhya G. and Dwivedi, S. M. (2018), "An Analytical Study on the HRD Techniques Implemented in State Bank of India", MERC Global's International Journal of Management, Vol. 6, Issue 3, pp. 95-106.

5. Sikula A. F. (1978), Personnel Administration and Human Resource Development, pp. 48.

6. Spears Marian. C. (2000), Food Service Organisation, A Managerial and System Approach, Merrill an imprint of Prentice Hall, New Jersey, Ohio.

7. Vetter, Eric W. (1967), "Manpower Planning for High Talent Personnel”, ERIC, pp. 5.

8. Wikstrom, W.S. (n.d.), "Manpower Planning, Evolving Systems", Conference Board Report, No. 521, New York. 